\title{
Phylogenetic analysis of the Antarctic genus Oswaldella Stechow, 1919 (Hydrozoa, Leptomedusae, Kirchenpaueriidae)
}

\author{
Alvaro L. Peña Cantero ${ }^{1} \&$ Antonio C. Marques ${ }^{2}$ \\ IDepartamento de Biología Animal, Facultad de Ciencias Biológicas, Universidad de Valencia, Dr. \\ Moliner 50, 46100 Burjassot, Valencia, Spain. E-mail: Alvaro.L.Pena@uv.es; ${ }^{2}$ Departamento de Biologia, \\ Faculdade de Filosofia, Ciências e Letras de Ribeînão Preto, Universidade de São Paulo. Av. Bandeirantes \\ 3900, 14040-901, Ribeirão Preto, SP, Brazil. E-mail: márques@ffclrp.usp.br
}

Keywords: Hydrozoa, Kirchenpaueriidae, Oswaldella, Antarctica, systematics, cladistics

\begin{abstract}
A cladistic study was carried out on known species of the characteristically Antarctic genus Oswaldella, adopting as outgroups some other genera included in the family Kirchenpauerìidae. The analysis resulted in a cladogram with low $\mathrm{CI}$ in which no relationship between genera can be depicted. However, the hypothesis of monophyly of the genus Oswaldella is corroborated, being supported in our cladogram by five synapomorphies (although all are homoplastic with other taxa or reversed within the species of the genus). The basal relationships of the genus are uncertain, but three species groups are distinguishable within Oswaldella: 1 ) the $O$. incognita group, $2)$ the $O$. antarctica group, and 3 ) a clade formed by $(O$. garciacarrascosai, $O$, elongata $(O$, blanconae $(O$, gracilis $U$. herwigi, Oswaldella sp. two)))).
\end{abstract}

\section{Contents}

$\begin{array}{ll}\text { Abstract } & 83 \\ \text { Introduction } & 83 \\ \text { Cladistic methods } & 84 \\ \text { Choice of out-groups } & 84 \\ \text { Results and discussion } & 85 \\ \text { Characters adopted } & 85 \\ \text { Phylogenetic hypothesis and discussion } & 87 \\ \text { Acknowledgements } & 91 \\ \text { References } & 92\end{array}$

\section{Introduction}

Phylogenetic studies on hydrozoan taxa have been few in number. In general, the systematics of the group is still based mainly on essentialistic principles. Examples of parsimony studies applied to hydrozoans are publications by Cairns (1984) on Stylasteridae, Marinopoulos (1992) using muddled methods on Eudendriidae (see Marques, 1996, for a reply and further comments), and Marques (1993, 1996), on Eudendriidae. Other phylogenetic studies include those of Bouillon, Boero \& GravierBonnet (1986), Petersen (1990), and Cunningham \& Buss (1993).

The family Kirchenpaueriidae and more broadly the taxa Plumulariida and Leptomedusae have been the subject of only one phylogenetic study (Boero, Bouillon \& Piraino, 1996). This is remarkable because these groups, when compared with anthomedusans, have a larger number of potential characters available for phylogenetic analyses. This paucity of phylogenetic studies may be due to a lack of general typological revisions of leptomedusan groups, the traditionalism of systematists of this group (cf. Marques, 1996), misconceptions concerning polymorphisms, and incomplete knowledge about life cycles in the group (cf. Migotto, 1998).

The genus Oswaldella Stechow, 1919a is one of the most diversified genera of Antarctic hydroids. Of some 21 known species, 20 are endemic to the Antarctic Region (the only exception, Oswaldella herwigi El Beshbeeshy, 1991, is Patagonian). This suggests an Antarctic origin of the genus (cf. Peña Cantero \& Vervoort, 1998), and its striking distribution suggests a possible monophyletic origin. The genus has been investigated in several recent works (Stepan'yants, 1979; El Beshbeeshy, 1991; Peña Cantero \& Vervoort, 1995, 1996, 1997, 1998; Peña Cantero, García Carrascosa \& Vervoort, 1995; Peña Cantero, Svoboda \& Vervoort, 1997), and a 
solid morphological knowledge of the taxon is available. Other genera of Kirchenpaueriidae, a family of worldwide distribution, are less well known, complicating the analyses here.

The goals of this study were to synthesize the characters of previous revisions of the genus Oswaldella in phylogenetic hypotheses, to test the validity of some species (such as those presented as Oswaldella sp. one and Oswaldella sp. two by Peña Cantero \& Vervoort, 1995), and to discuss the applicability of some characters and further implications of the phylogenetic hypothesis in the evolution of the genus.

\section{Cladistic methods}

The phylogenetic analysis was performed following the major principles proposed by Hennig (1966), and general methods described by Forey et al. (1992), Marques (1996), Ferrarezzi \& Marques (1997) and Simões, Marques, Mello \& Anelli (1997).

The characters were ordered whenever information about ontogeny was present, or when the existence of contiguity of similarity among the states of the character was clear. The parsimony analysis was performed using TreeGardener v. 2.2 (Ramos, 1997) emulating Hennig86 (Farris, 1988), employing the heuristic algorithms " $\mathrm{mh}^{*} ; \mathrm{bb}^{* \prime}$. The strict (Sokal \& Rohlf, 1981) and semi-strict (Bremer, 1990) consensus trees were derived for the most parsimonious trees. The matrix was built using as many "out-groups" as possible (see the exposition about taxa adopted as out-groups below), to assure a more efficient optimization of the characters (Nixon \& Carpenter, 1993). Firstly, an unrooted network was considered, and this was $a$ posteriori rooted using ontogenetic or «out-group» principles (Nixon \& Carpenter, 1993; De Pinna, 1994). Whenever necessary in the discussion, we adopted the group+ artifact, i.e., the whole clade is indicated by the addition of a " $t$ " mark to its most basal group (Amorim, 1982).

Although autapomorphic characters of the outgroup taxa are not informative for sorting relationships among the species of the in-group, we decided to include these characters as well (num- bers $19,20,22$ ). The systematics of the family Kirchenpaueriidae is confusing, and we considered that any information about the monophyly of genera and species groups would be important to guide future studies.

\section{Choice of out-groups}

The major question whether to choose one or several taxa that could be used as out-groups for this analysis was related to polymorphisms among the species included in the family Kirchenpaueriidae, and to the lack of a general recent revision for this family. Bouillon's (1985) synopsis, which recognized five genera in the family, constitutes a unique compendium for classification of the group.

The genus Halicornopsis Bale, 1882, includes two known species, both distributed in Australian waters. Halicornopsis elegans Lamarck, 1816 and $H$. avicularis Bale, 1882 are poorly known species that have been recorded only a few times. Halicornopsis is characterized by the denticulated rim of the hydrothecal aperture (Bouillon, 1985), a feature also shared with some genera of the family Aglaopheniidae. Because of this we decided not to consider this genus within the potential outgroups for Oswaldella due to its uncertain position.

The genus Ophinella Stechow, 1919b, is monotypic. The only known species, $O$. parasitica G.O. Sars, 1874 , is distinguishable by its long urticating organs that bear nematocysts on their capitate tips. The position of the genus is uncertain; Stechow (1919b) and Bedot (1923) placed the genus in Kirchenpaueriidae, whereas Sars (1874, original description as Ophiodes parasitica), Allman (1883), Bonnevie (1899), and Jãderholm (1909) placed the species in Halecilidae, drawing similarities to the genus Hydrodendron Hincks, 1874. These facts led us to consider Ophinella a useless out-group for the analysis.

The genus Pycnotheca Stechow, 1919b, is characterized by the presence of an abcauline intrathecal septum (Bouillon, 1985). The genus includes two species: $P$. mirabilis (Allman, 1883), which is herein adopted as an out-group of Oswaldella, and $P$. producta (Bale, 1882; not included as outgroup). The choice of only one of the species of 
the genus was related to the total available information about them.

The last genus recognized as valid by Bouillon (1985) was Kirchenpaueria Jickeli, 1883, with some 20 nominal species. According to Bouillon (1985: 169; herein translated to English), it is characterized as follows "Branched or unbranched, monosiphonic or polysiphonic colonies. Hydrothecal marginal rim non-denticulated. Hydrotheca without intrathecal septum. Unforked hydrocladia. Mesial nematotheca present or not, when present either superior or inferior or in both positions". Hence, it is clear that, at least in an essentialistic view (by now independent of a phylogenetic approach), Kirchenpaueria is mainly characterized by the lack of the diagnostic features of the other genera of the family.

Bouillon considered Ventromma Stechow, 1923 a junior synonym of Kirchenpaueria. Nevertheless, in several recent papers other authors have treated it as a valid genus (Cornelius, Manuel \& Ryland, 1990; Boero \& Bouillon, 1993; Vervoort, 1993; Medel \& Vervoort, 1995; Migotto, 1996; Calder, 1997). We concur based on a study of the type species of both genera. It is possible to note distinct differences between them: in Ventromma, the mesial superior nematophore in the hydrothecate hydrocladial internodes is provided with a nematotheca, whereas in Kirchenpaueria that nematophore is naked. Moreover, the cauline nematophores are also provided with a nematotheca in Ventromma, whereas they are naked in Kirchenpaueria.

In conclusion, the genus Kirchenpaueria is considered a useful out-group of Oswaldella, and constitutes a unique operational taxonomic unit clearly separated from Ventromma, another useful out-group. The need for a full revision of the species of Kirchenpaueria, indeed all Kirchenpaueriidae, is clear.

Recently, a new genus, Naumovia, has been established by Stepan'yants, Peña Cantero, Sheiko \& Svoboda (1997). Its only known species, $N$. microtheca (Naumov, 1960), is distinctively characterized by the absence of a mesial inferior nematophore in the hydrothecate hydrocladial internodes. As an additional taxon for the family Kirchenpaueriidae, in which relationships among the taxa are unknown, this genus is adopted here as an out-group of Oswaldella.

\section{Results and discussion}

\section{Characters adopted}

The characters used in this study are presented below. Unless otherwise noted, information on the following taxa was obtained as follows: Oswaldella spp. (Peña Cantero \& Vervoort, 1995, 1996, 1997 , 1998; Peña Cantero et al., 1995, 1997); Pycnotheca mirabilis (Millard, 1975); Kirchenpaueria spp. (Medel \& Vervoort, 1995 and personal observations); Ventromma spp. (Ramil \& Vervoort, 1992; Medel \& Vervoort, 1995, and personal observations); and Naumovia (Stepan'yants et al., 1997, and personal observations). All data concerning the characters are summarized in the matrix of Table 1; some characters are represented in Fig. 1.

Table 1. Matrix used for the cladistic analysis of Oswaldella spp. following the remarks stated in the exposition of the characters. Polymoriphic characters and non-comparable characters are coded as hyphens ("-"), and missing data are coded as question marks ("7").

\begin{tabular}{|c|c|c|c|c|}
\hline Taxon & $\begin{array}{l}00000 \\
12345\end{array}$ & $\begin{array}{l}00001 \\
67890\end{array}$ & $\begin{array}{l}11111 \\
12345\end{array}$ & $\begin{array}{l}11112 \\
67890\end{array}$ \\
\hline irch & 000 & 00005 & 02000 & -000 \\
\hline Ventro & -000 & $0-00-$ & $0-00$ & -100 \\
\hline Pycnotheca & 00000 & 01015 & 01000 & -0001 \\
\hline Naumovia & 0000 & 00001 & $010-1$ & -0110 \\
\hline O. bifurca & 00011 & 00203 & 10011 & 00000 \\
\hline 0. antarctica & 0000 & 11210 & 01000 & 00000 \\
\hline O. erratum & 0210 & 10211 & 11000 & 00000 \\
\hline$O$. shetlandic & 001 & 12211 & 10 & 00 \\
\hline $0 . h$ & 001 & 01104 & 02001 & 00 \\
\hline O. $s$ & 1000 & $1-210$ & 01000 & 00000 \\
\hline O. blanconae & 0001 & 01100 & 00010 & 00000 \\
\hline O. elongata & 0001 & 12110 & 01010 & 00000 \\
\hline O. ter & 1000 & 12210 & 01000 & 00000 \\
\hline $0 . t$ & 0100 & 10100 & $0 ? 001$ & 00000 \\
\hline O. delicata & 0000 & 00110 & 01000 & 00000 \\
\hline O. encarnae & 0000 & 10000 & 01000 & -0000 \\
\hline O. garciacarrascosai & 3001 & 11110 & 01000 & 00000 \\
\hline O. gracilis & 1001 & $00 ? 02$ & 01000 & -0000 \\
\hline indis & 100 & 12200 & 07001 & 00000 \\
\hline gnita & 00000 & 10110 & 11000 & 00000 \\
\hline cura & 11100 & 11110 & 01000 & 00000 \\
\hline$i d a$ & 01110 & 10212 & 11000 & 00000 \\
\hline$O$. sp. one & 01000 & 00210 & 01000 & 00000 \\
\hline$O$. sp. two & 00000 & 01702 & 02000 & 00000 \\
\hline O. crassa & 00201 & 11210 & 11011 & 00000 \\
\hline O. curiosa & 00001 & 00214 & 11100 & 10000 \\
\hline O. billardi & 00000 & 10111 & 02000 & 00000 \\
\hline
\end{tabular}


Character 1: Stem conformation $(0=$ monosíphonic, $1=$ polysiphonic). Contrary to the information of Bouillon (1985: 169) that Kirchenpaueria can assume both monosiphonic and polysiphonic conformations, we herein assume the monosiphonic habit as characteristic for species of this genus, since we are considering Ventromma, with species showing polysiphonic and monosiphonic stems, as a valid genus.

Character 2: Branching of the stem ( $0=$ unbranched, $1=$ branched). The same aspects noted for character 1 are also valid for this character, since Bouillon (1985) also considered Kirchenpaueria as having both unbranched and branched stem. We recognized only unbranched species of Kirchenpaueria; Ventromma spp. possibly represent the branched hydroids of "Kirchenpaueria» considered by Bouillon (1985).

Character 3: Cauline internodes $(0=$ internodes always present, 1 = with occasional internodes, 2 $=$ without internodes). This character is considered non-additive in the analysis, since there is no indication of an eventual ontogenetic or contiguity order. The state with occasional internodes is considered different from the state in which the internodes are always present because the former is probably due to interruption in the development of the colony whereas the latter is considered a constant feature.

Character 4: Angle between cauline apophysis and stem $\left(0=45^{\circ}, 1=>70^{\circ}\right)$. This character is a continuous one, but even so it is adopted because there is a clear gap between the two groups. Character state 0 is always constant around $45^{\circ}$, but state 1 may vary between $70^{\circ}$ and $90^{\circ}$. Nevertheless, the variation observed in state 1 is considered to be a primary homology (sensu De Pinna, 1991).

Character 5: Mesial inferior nematotheca $(0=$ present, 1 = absent). When a nematotheca is present (state 0 ), it has either a conspicuous scale-shaped form (e.g., Oswaldella incognita Peña Cantero et al., 1997), or is inconspicuous [e.g., Oswaldella antarctica (Jäderholm, 1904)]. Nevertheless, the inconspicuous nematotheca was not considered a subdivision of the state due to the difficulty in the definition and delimitation of these putative states.

Character 6: Number of axillary nematophores ( $0=$ one nematophore, $1=$ more than one). Char- acter state 1 is usually related to the presence of two nematophores. Nevertheless, Oswaldella stepanjantsae El Beshbeeshy, 1991 seems to have two or four of these structures, but it is also coded as state 1. This assumption has no further implication for the cladistic analysis, since this possible polymorphism, if it actually exists, would lead one to consider the character as an additive one, and therefore the presumptive state 2 (meaning the eventual presence of 4 nematophores) would be not informative and autapomorphic for $O$. stepanjantsae.

Character 7: 'Mamelons' ( $0=$ absent, $1=$ one 'mamelon", 2 = two 'mamelons'). A clear polymorphic condition for this character is presented by Oswaldella stepanjantsae. This species has colonies without "mamelons" (state 0 ) as well as colonies with two "mamelons" (state 2). In the matrix, this polymorphic condition is coded as «-»). Oswaldella grandis Peña Cantero et al., 1997 usually has two 'mamelons", but the last cauline apophyses lack them. This fact could be due to ontogenetic development, since the apical parts are younger. According to De Pinna (1994), this aspect could determine a polarity in an unrooted tree, also used in this analysis to test the out-group information about the root point.

Character 8: Maximal order of hydrocladia ( 0 = first, $1=$ second, 2 = third or fourth). Oswaldella gracilis Peña Cantero et al., 1997 has only first-order hydrocladia, but as was already pointed out by those authors, the specimen described could be a young colony. The available material of Oswaldella sp. one had only four hydrocladia which did not allow a reliable character state designation for the species. Both of these aspects prevented us from considering the information for these species (represented in the matrix by a question mark). Oswaldella sp. two was also described from scarce material. However, it has at least second order hydrocladia, corresponding to states 1 or 2 . Though this information was considered in the cladistic analysis when interpreting the resulting cladograms, it was also coded with a question mark in the data matrix. In species of Kirchenpaueria, the gonothecae are placed on the stem or on the cauline apophyses. Oswaldella encarnae Peña Cantero et al., 1997, which has unforked hydrocladia, differs in having gonothecae on the hydrocladia. The 
change from possession of unbranched hydrocladia to second-order hydrocladia (state 1) is interpreted by us as an important step in the evolution of Oswaldella. A further step would be the increase in number of the hydrocladia (state 2), which could play an important role in the defense of the gonothecae. Hydrocladia tend to be arranged hemispherically, forming a protected zone between stem and hydrocladia in which the gonothecae are situated. This, and the existence of contiguous successive branching, induced us to treat the character as additive.

Character 9: Height of hydrotheca $(0=10 w, 1=$ high). We have considered as low hydrothecae those in which height is equivalent to the diameter of the hydrothecal aperture; in those considered high, the hydrotheca is deeper than wide.

Character 10: Hydrothecal aperture $(0=$ even; $1=$ adcaudally directed, $2=$ laterally depressed, 3 $=$ frontally depressed, $4=$ abcaudally directed with asymmetrical hydrotheca, $5=$ abcaudally directed with symmetrical hydrotheca). This character is composed of several states without relation of order. Hence, it is considered nonadditive in the analysis. We changed some aspects in the interpretation of this character from the Appendix presented by Peña Cantero et al. (1997). First, laterally depressed, as defined for Oswaldella gracilis, also includes the adcauline elevation of Oswaldella rigida Peña Cantero et al., 1997. This also occurs in Oswaldella sp. two (fig. 3 in Peña Cantero \& Vervoort, 1995). Second, we have considered $O$. herwigi to have an even but abcaudally directed hydrothecal aperture. Character state 4 of Oswaldella curiosa Peña Cantero \& Vervoort, 1998 is also abcaudally directed as in $O$. herwigi.

Character 11: Node between apophysis and hydrocladia $(0=$ present, $1=$ absent $)$

Character 12: Position of the hydrotheca on the internode $(0=$ basal, $1=$ in the middle, $2=$ distal). To avoid problems in understanding information given by Peña Cantero et al. (1997), we consider only the three states described above. Therefore, the conditions "distal half" and "distal third" of these authors are grouped as «distal» in this analysis. The character is considered additive in the analysis.

Character 13: Branch end $(0=$ truncated end,
$1=$ pointed end). The only species having hydrocladia terminated in an internode with pointed end are Oswaldella shetlandica Stepan'yants, 1979, and $O$. curiosa. This internode is the terminal addition of the ontogenetic sequence; therefore it is justifiable to consider the pointed end as the apomorphic state of the truncated end, restricting the places for possible root of the unrooted MPT.

Character 14: Angle formed by the longitudinal axis of the hydrocladial internode and the side of the infrathecal elevation from where the mesial inferior nematophore emerges $\left(0=<90^{\circ} ; 1=90^{\circ}\right)$.

Character 15: Conspicuous free portion of the adcauline hydrothecal wall $(0=$ present, $1=$ absent).

Character 16: Hydrocladial arrangement $(0=$ symmetric, $1=$ asymmetric). All the species with forked hydrocladia, with the exception of $O s$ waldella kerwigi and $O$. curiosa, have a symmetrical disposition of the higher-order hydrocladia. $O$ swaldella encarnae and $O$. gracilis have unbranched hydrocladia and so this character is not comparable for them.

Character 17: Hydrocladial internodes $(0=$ homomerous; $1=$ heteromerous). Though the homomerous hydrocladial division into internodes (i.e., only thecate internodes) is the common condition in Oswaldella spp., $O$. herwigi has alternate series of thecate and athecate internodes.

Character 18: Mesial superior nematophore $(0=$ naked, $1=$ with nematotheca). This character is distinctive for Ventromma in relation to Kirchenpaueria.

Character 19: Mesial inferior nematophore ( $0=$ present, $1=$ absent).

Character 20: Intrathecal septum $(0=$ absent, 1 = present).

Character 21: Cauline nematophore $(0=$ present, $1=$ absent).

Character 22: Cauline nematophore $(0=$ with nematotheca, $1=$ naked).

\section{Phylogenetic hypothesis and discussion}

A maximum parsimony analysis resulted in 14 most parsimonious unrooted trees (MPUTs) $(\mathrm{L}=76$; $\mathrm{CI}=0.39 ; \mathrm{RI}=0.55$ ). Due to the low CI of these unrooted cladograms, we conducted a PTP analy- 

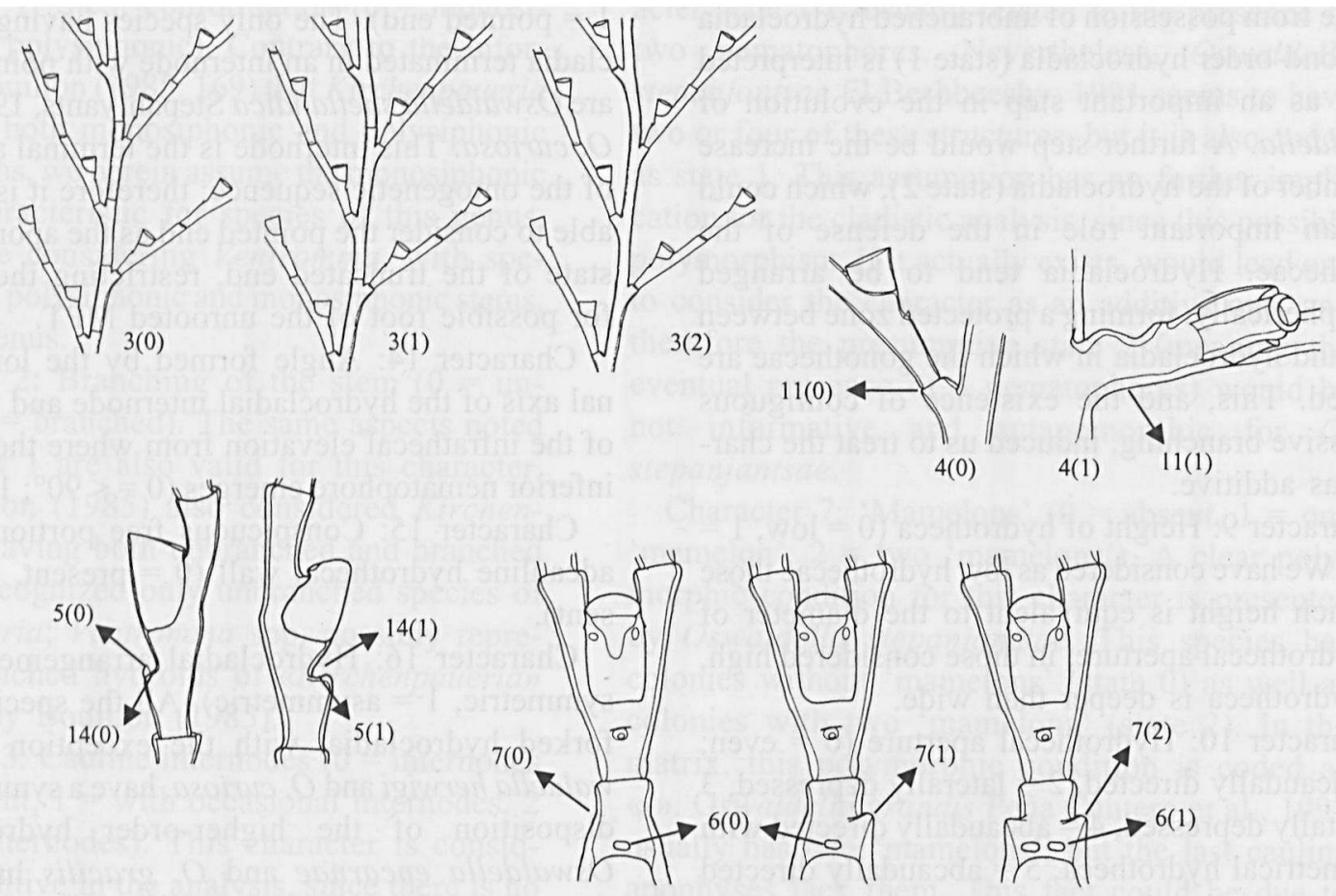

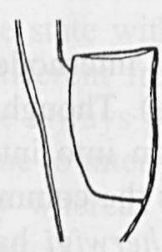

$10(0)$

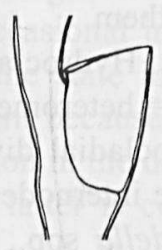

$10(1)$

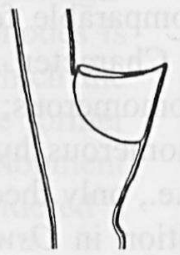

10(2)

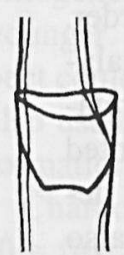

10(3)

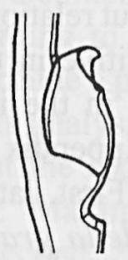

$10(4)$

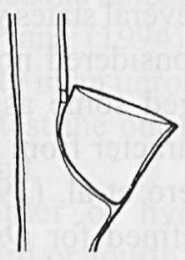

$10(5)$

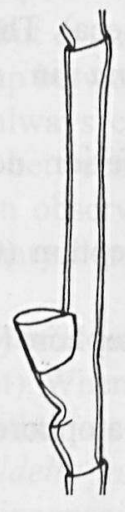

$12(0)$

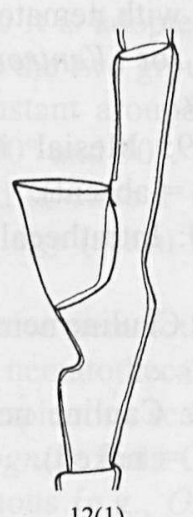

12(1)

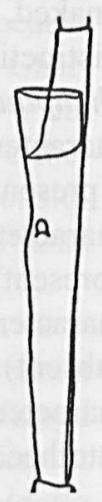

12(2)

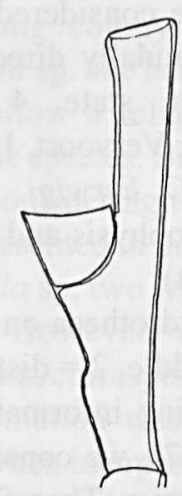

13(0)

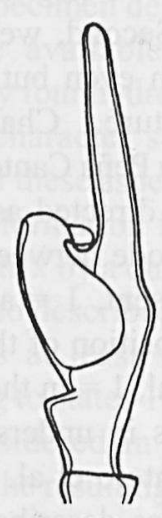

13(1)

Fig. 1. Morphological representations of the different states of characters used in the analysis (the numbers in the figs. refer to the character states listed in the text). 


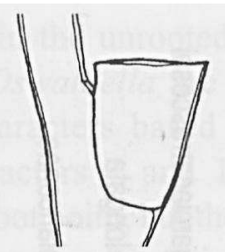

$15(0)$

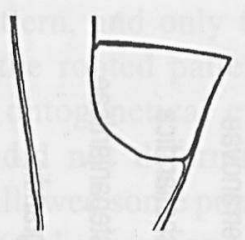

15(1)

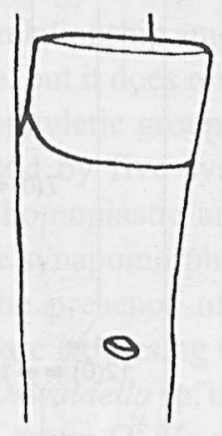

19(0)

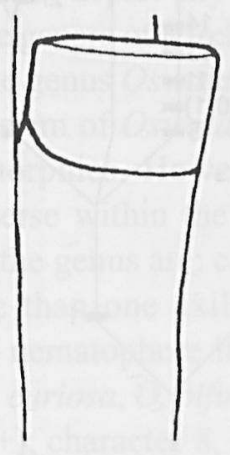

19(1)

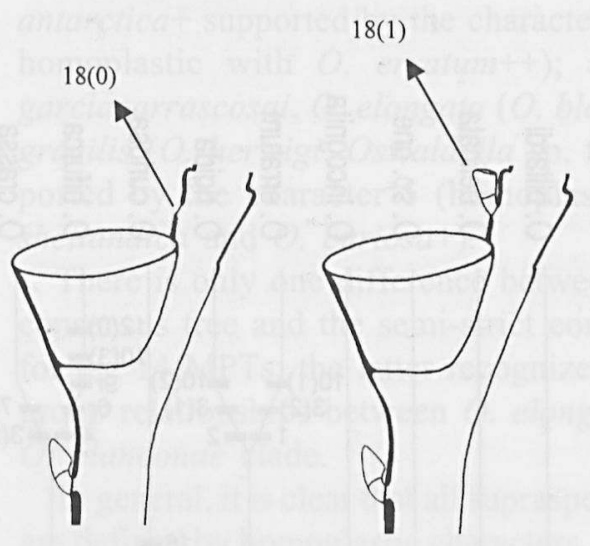

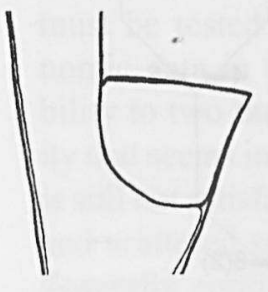

20(0)

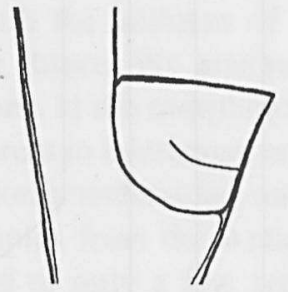

20(1)
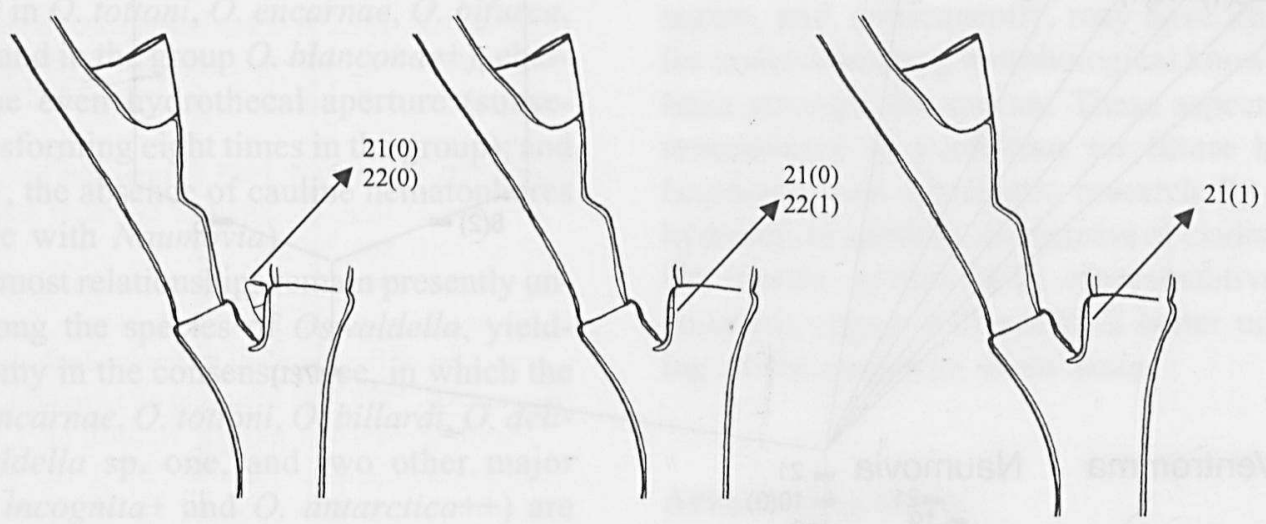

Fig. 1. Continued.

sis ("permutation tail probability" test, see Faith \& Cranston, 1991) to test the possibility that the matrix could produce the same results "randomly". We removed the autapomorphic characters and the resulting similar taxa were merged into single operational taxonomic units to avoid bias in the test. The result rejected the null-hypothesis, i.e., that the matrix could be generated randomly $(P$ value $=0.02$ )

The strict consensus of the MPUTs ( $\mathrm{L}=81$; $\mathrm{CI}=0.37 ; \mathrm{RI}=0.50$ ) was rooted between the "outgroup" and "in-group" taxa, in accordance with the procedure of Nixon \& Carpenter (1993). Nevertheless, we prefer to represent the out-group taxa 


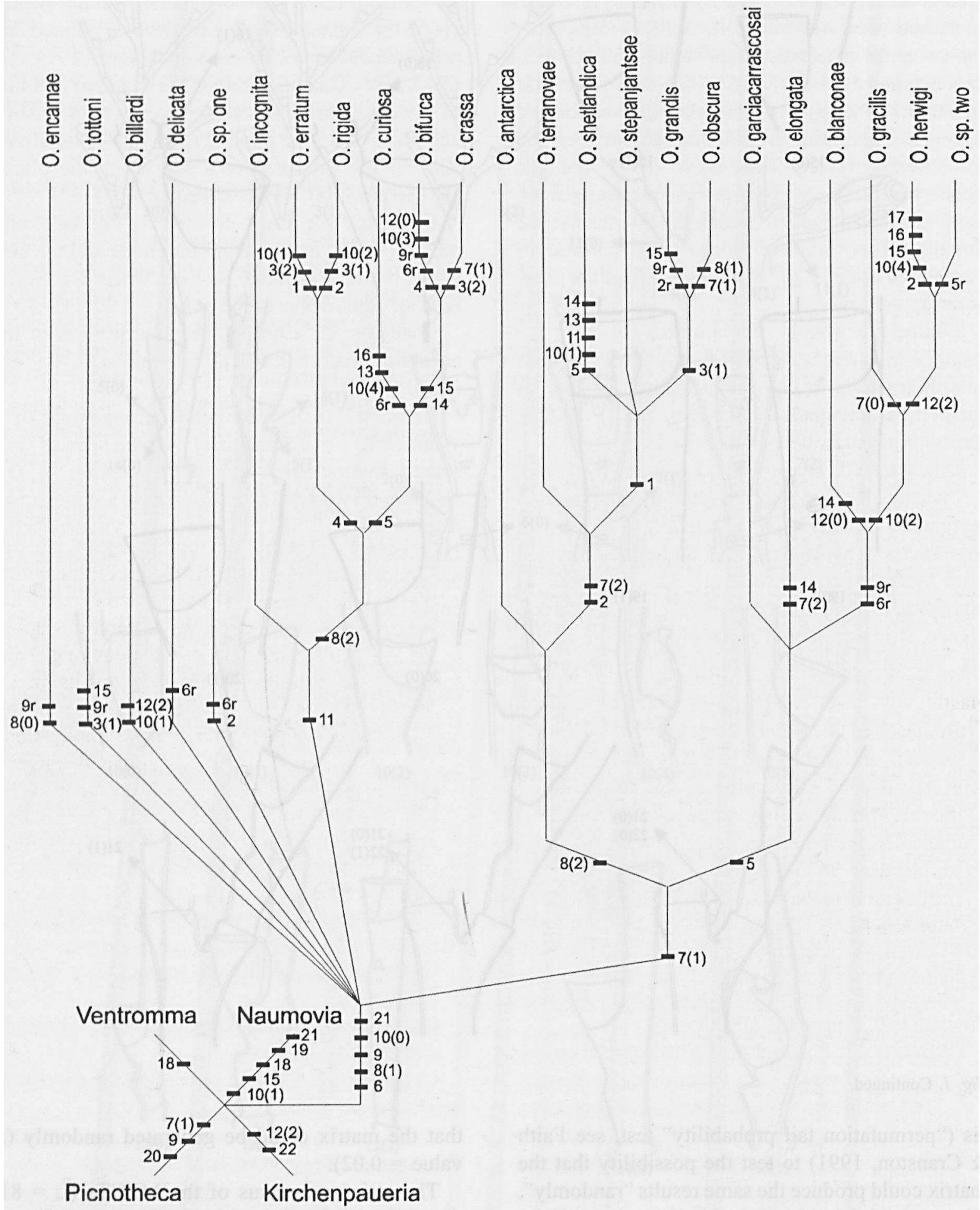

Fig. 2. Strict consensus cladogram $(\mathrm{L}=81, \mathrm{CI}=0.37, \mathrm{RI}=0.50)$ of 14 most parsimonious trees $(\mathrm{L}=76, \mathrm{CI}=0.39, \mathrm{RI}=0.55)$. The outgroups are kept in an unrooted form and onlv the in-group (Oswaldella) is rooted. A semi-strict consensus would join the species $O$. elongata with the clade $O$. blanconaet. 
graphically in the unrooted pattern, and only the species of Oswaldella are in the rooted pattern. The two characters based on ontogenetical evidence (characters 7 and 13) did not determine precisely a root point, but they allowed some points among the out-group terminals (and several among the in-group taxa) for the location of the root (De Pinna, 1994). This procedure then allowed a character polarity for our working hypothesis for the group (Fig. 2).

The topology of Fig. 2 does not depict any sister-group relationship among the genera of Kirchenpaueriidae, but it does reveal the genus Oswaldella as a monophyletic group. The stem of Oswaldella is supported by five synapomorphies. However, these are homoplastic and reverse within the genus. These synapomorphies of the genus are: character 6, the presence of more than one axillary nematophore (reversing to one nematophore in $O$. delicata, Oswaldella sp. one, $O$. curiosa, 0 . bifurca, and in the group $O$. blanconaet); character 8, second-order hydrocladia (reversing to first-order hydrocladia in $O$. encarnae and evolving to the third or fourth order in $O$. erratum+t and $O$. antarctica+): character 9, high hydrothecae (homoplastic with Pycnotheca and reversing to low hydrothecae in 0 . tottoni, O. encarnae, 0 . bifurca, $O$. grandis, and in the group O. blanconae+); character 10 , the even hydrothecal aperture (subsequently transforming eight times in the group); and character 21 , the absence of cauline nematophores (homoplastic with Naumovia).

The basalmost relationships remain presently undefined among the species of Oswaldella, yieldIng a polytomy in the consensus tree, in which the species $O$. encarnae, $O$. tottoni, $O$. billardi, $O$. delicata, Oswaldella sp. one, and two other major groups (O. incognita+ and $O$. antarctica ++ ) are placed.

The first of these, the $O$. incognita species group, 1s supported by character 11 (absence of node between apophysis and hydrocladia), but this is homoplastic with $O$. shetlandica.

The second, $O$. antarctica group, contains all remaining species. It is supported only by the presence of one mamelon (character 7, which in turn is modified four times inside the group), and is homoplastic with Pycnotheca and O. crassa. The group is composed of two minor clades: 1) 0 . antarctica+ supported by the character 8 (state 2; homoplastic with $O$. erratum++); and 2) $(O$. garciacarrascosai, $O$. elongata $(O$. blanconae $(O$. gracilis (O. herwigi, Oswaldella sp. two)))) supported by the character 5 (homoplastic with $O$. shetlandica and 0 . curiosa+).

There is only one difference between the strict consensus tree and the semi-strict consensus tree for the 14 MPTs; the latter recognizes the sistergroup relationships between $O$. elongata and the O. blanconae clade.

In general, it is clear that all supraspecific groups are defined by homoplastic characters. A bootstrap analysis (Felsenstein, 1985) showed that all the supraspecific clades have low bootstrap proportion values (BP < 40). This suggests high level of instability for the present hypothesis, which thus must be tested with the addition of further taxonomic data in the future. We attribute this instability to two factors: 1) the morphological plasticity that seems inherent in hydrozoan taxa, and which is still not satisfactorily understood, and 2) restricted and scattered samples from the Antarctic Region, generally confined to only a few areas (e.g. Antarctic Peninsula), which possibly results in an underestimation of the number of species in the region, and, consequently, may have implications for underestimating morphological knowledge and links amongst the species. These aspects must be remembered as guidelines for future hydrozoan taxonomic and systematic research for Antarctic hydroids. In addition, an increase of cladistic studies for marine groups with representatives in the Antarctic region will permit a better understanding of the evolution of its biota.

\section{Acknowledgements}

The authors are deeply indebted to Prof. Dr. Wim Vervoort (Nationaal Natuurhistorisch Museum - Leiden, Netherlands) for his extensive support to this study (largely done in his laboratory) and comments on the manuscript. Dr. Alvaro E. Migotto (Centro de Biologia Marinha da Universidade de São Paulo-São Sebastião, Brazil), Prof. Dr. Frederick Schram (Universiteit van Amsterdam), and Dr. D.R. Calder also made valuable suggestions to a previous version of the text. The study was supported by FAPESP (grant 96/10544-0). Alvaro L. Peña Cantero had financial support from the Secretaria de Estado de Universidades, Investigación y Desarrollo del Ministerio de 
Educación y Ciencia of Spain (Ref. ANT97-2097/E), Antonio C. Marques had a personal grant from FAPESP (97/04572-4).

\section{References}

Allman GJ. 1883. Report on the Hydroida dredged by H.M.S. Challenger during the years 1873-1876. Part I. Plumularidae. Rep. Scient. Results Voy, Challenger (Zool.) 7: 1-54.

Amorim DS. 1982. Classifícação por seqũenciação: uma proposta para a denominação dos ramos retardados. $R e v$. Bras. Zool, 1: 1-9.

Bale WM. 1882. On the Hydroida of south-eastern Australia, with descriptions of supposed new species, and notes on the genus Aglaophenia. J. microsc. Soc. Vict. 2; 15-48.

Bedot M. 1923. Notes systếmatiques sur les Plumularides. 3me partie. Revue Suisse Zool. 30: 213-243.

Boero F, Bouillon J. 1993. Zoogeography and life cycle patterns of Mediterranean hydromedusae (Cnidaria). Biol. J. Linn. Soc, 48: 239-266.

Boero F, Bouillon J, Piraino S. 1996. Classification and phylogeny in the Hydroidomedusae (Hydrozoa, Cnidaria). Sci. Mar. 60: 17-33.

Bonnevie K. 1899. Hydroida. Norske Nordhavs-Exped. 26: 1-103.

Bouillon J. 1985. Essai de classification des HydropolypesHydroméduses (Hydrozoa-Cnidaria). Indo-Malayan Zool. 2 : 29-243.

Bouillon J, Boero F, Gravier-Bonnet N. 1986. Pseudostenotele, a new type of nematocyst, and its phylogenetic meaning within the Haleciidae (Cnidaria, Hydrozoa). Indo-Malayan Zool. 3: 63-69.

Bremer K. 1990. Combinable component consensus. Cladistics 6: 369-372.

Cairns SD. 1984. A generic revision of the Stylasteridae (Coelenterata: Hydrozoa). Part 2; phylogenetic analysis. Bull. Mar, Sci. 35: 38-53.

Calder DR. 1997. Shallow-water hydroids of Bermuda: superfamily Plumularioidea. Life Sci. Contrib. R. Ontario Mus. 161: $1-80$.

Cornelius PFS, Manuel RL, Ryland JS. 1990. Cnidaria. In: Hayward PJ, Ryland JS, eds. The marine fauna of the British Isles and North-West Europe. Volume 1, Introduction and Protozoans to Arthropods. Oxford: Oxford University Press, 101-200.

Cunningham CW, Buss LW. 1993. Molecular evidence fór multiple episodes of paedomorphosis in the family Hydractinildae. Bioch. Syst. Ecol. 21: 57-69.

EI Beshbeeshy M. 1991. Systematische, Morphologische und Zoogeographische Untersuchungen an den Thekaten Hydroiden des Patagonischen Schelfs. Ph.D. thesis, University of Hamburg, Germany, 1-390.

Faith DP, Cranston PS. 1991. Could a cladogram this short arisen by chance alone? On permutation tests for cladistic structure. Cladistics 7: 1-28.

Farris JS. 1988. Hennig86 Reference. Version 1.5.
Felsenstein J. 1985. Confidence limits on phylogenies: an approach using the bootstrap. Evolution 39: 783-791.

Ferrarezzi H, Marques AC. 1997. Cap. 13. Análíse cladística numérica e recursos computacionaìs. In: Amorím DS, ed. Elementos Básicos de Sistemática Filogenética, 2a. Ediçẫo Ribeirẫo Preto: Sociedade Brasileira de Entomologia/Holos Editora, 161-186.

Forey PL, Humphries CJ, Kitching IL, Scotland RW, Siebert DJ, Williams DM. 1992. Cladistics, a practical course in systematics. Oxford: The Systematics Association Publication no. 10.

Hennig W. 1966. Phylogenetic systematics. Urbana: University of Illinois Press.

Hincks T* 1874, On deep-water Hydroida from Iceland. Ann. Mag. nat. Hist. 13: 146-153.

Jäderholm E. 1904. Mitteilungen über einige von der schwedischen Antarctic-Expedition 1901-1903 eingesammelte Hydroiden. Archs Zool. Exp. Gén. 4 (notes et revue 1): 114.

Jäderholm E. 1909. Northern and Arctic invertebrates. IV. Hydroïden. $K$. Svenska Vetensk Akad. Handl, 45. 1-124.

Jickeli CF. 1883. Der Bau der Hydroidpolypen. Morph. Jb. 8: 373-416, 580-680.

Lamarck JB. 1816. Histoire naturelle des animawx sans vertèbres. Vol. 2. París: Verdière.

Marinopoulos J. 1992. Contribution à l'étude du genre Eudendrium (Hydrozoa: Hydroida) de la Médíterranée: taxonomie et phylogénie. Bull. Inst. océanogr. Monaco 9: 53-66.

Marques AC. 1993. Sistemática dos Eudendrildae L. Agassiz, 1862 (Cnidaria, Hydrozoa) do litoral paulista. MSc. Dissertation, Instituto de Biociências, USP, São Paulo, Brazil, 1-168.

Marques AC. 1996. A critical analysis of a cladistic study of the genus Eudendrium (Cnidaria: Hydrozoa), with some comments on the family Eudendriidae. J. Comp. Biol. 1: 153162 .

Medel MD, Vervoort W. 1995. Plumularian hydroíds (Cnídaria: Hydrozoa) from the Strait of Gibraltar and nearby areas. Zool. Verh. 300: 1-72.

Migotto AE. 1996. Benthic shallow-water hydroids (Cnidaria, Hydrozoa) of the coast of São Sebastião, Brazil, including a checklist of the Brazilian hydroids. Zool. Verh. 306: 1-125.

Migotto AE. 1998. The life cycle of Sertularia marginata Kirchenpauer, 1864 (Cnidaria, Hydrozoa): a medusoid-producing sertulariid $J$. Nat. Hist. 32: 1-12.

Millard NAH. 1975. Monograph on the Hydroida of southern Africa. Ann. S. Afri. Mus. 68: 1-513.

Naumov DV. 1960. Gidroidi i gidromedusy morskikh, solonovatovodnykh i presnovodnykh basseinov SSSR. - Opredeleteli po faune SSSR, Izdavaemye Zoologicheskim Institutom Akademil Nauk SSSR 70: 1-626 (in Russian). English translation (1969) by Israel Program for scientific translations, cat. no. 5108, as \&Hydroids and Hydromedusae of the USSR;, 1-631.

Nixon KC, Carpenter JM. 1993. On outgroups. Cladistics 9: 413-426. 
Peña Cantero AL, García Carrascosa AM, Vervoort W. 1995. On two Antarctic species of Oswaldella Stechow, 1919; $O$. shetlandica Stepan'yants, 1979 and $O$. elongata spec. nov. (Cnidaria Hydrozoa) (Notes on Antarctic hydroids, II). Zool. Meded. 69: 341-351.

Peĩa Cantero AL, Svodoba A, Vervoort W. 1997. Species of Oswaldella Stechow, 1919 (Cnidaria, Hydrozoa) from recent Antarctic expeditions with R.V. «Polarstern», with the description of eight new species. Zool. J. Linn. Soc. 119: 339. 388.

Peña Cantero AL, Vervoort W. 1995. Redescription of Oswaldella antarctica (Jäderholm, 1904) (Cnidaria Hydrozoa) with notes on related species (Notes on Antarctic hydroids, I). Zool. Meded. 69: 329-340.

Peña Cantero AL, Vervoort W. 1996. On two new species of Oswaldella Stechow, 1919; $O$, terranovae spec. nov and $O$. tottoni spec. nov. (Cnidaria: Hydrozoa). Notes on Antaretic hydroids, III. Zool. Meded. 70: 135-143.

Peña Cantero AL, Vervoort W. 1997. On Oswaldella billardi Briggs, 1938 and $O$. erratum spec. nov, two Antarctic hydroid species (Cnidaria, Hydrozoa). Zool. Meded. 71: 269-276.

Peña Cantero AL, Vervoort W. 1998. On two new species of Oswaldella Stechow, 1919 (Cnidaria, Hydrozoa) from Bransfield Strait (Antarctica). Polar Biol. 20: 33-40.

Petersen KW. 1990. Evolution and taxonomy in capitate hydroids and medusae. Zool. J. Linn. Soc. 100: 1-231.

Pinna MCC. de 1991. Concepts and tests of homology in the cladistic paradigm. Cladistics 7: 367-394.

Pinna MCC. de 1994. Ontogeny, rooting and polarity. In: Scotland RW, Siebert DJ, Williams DM, eds. Models of Phylogeny Reconstruction. Oxford: Clarendon Press, 157-172.

Ramos TC. 1997. TreeGardener v. 2.2 software and manual. Available in the homepage of the Willi Hennig Society.

Ramil F, Vervoort W. 1992. Report on the Hydroida cóllected by the "BALGIM" expedition in and around the Strait of Gibraltar. Zool. Verh. 277: 3-262.

Sars GO. 1874. Bidrag til kundskaben om Norges Hydroider. Forh. Vidensk/Selsk. Christiania 1873: 91-150.

Simões MG, Marques AC, Mello LHC,Anelli LE. 1997. Phylogenetic analysis and evolution of the genera of the extinct family Megadesmidae (Bivalvia, Anomalodesmata). J. Comp. Biol. 2: 75-90.

Sokal RR, Rohlf FJ. 1981. Taxonomic congruence in the Lepopodomorpha reexamined. Syst. Zool. 30: 309-325.

Stechow E. 1919a. Neue Ergebnisse auf dem Gebiete der Hydroidenforschung. München, mediz, Wochenschr. 1919; 852-853.

Stechow E. 1919b. Zur Kenntis der Hydroidenfauna des Mittelmeeres, Amerikas und anderer Gebiete, nebst Angaben über einige Kirchenpauer'sche Typen von Plumulariden. Zool. Jb. Syst. 42: 1-172.

Stechow E. 1923. Zur Kenntis der Hydroídenfauna des Mittelmeeres, Amerikas und anderer Gebiete. II. Teil. Zool. Jb. Syst. 47: 29-270, pls. 1-35.

Stepan'yants SD. 1979. Hydroids of the antaretic and subantarctic waters. In: Biological results of the Soviet Antarctic Expeditions, 6 (in Russian). Issled. Fauny Morei 22: 1-200.

Stepan'yants SD, Peîa Cantero AL, Sheiko OV, Svoboda A. 1997. Naumovia gen. n. for Plumularia microtheca Naumov, 1960 , a deepwater North Pacific species, with remarks on other genera and species of the family Kirchenpaueriidae (Cnidaria, Hydrozoa). Zoosyst. Rossica 6: 9-20.

Vervoort W. 1993. Report on hydroids (Hydrozoa, Cnidaria) in the collection of the Zoological Museum, University of Tel-Aviv, Israel, Zool. Meded. 67: 537-565.

Received: 10 September 1998 